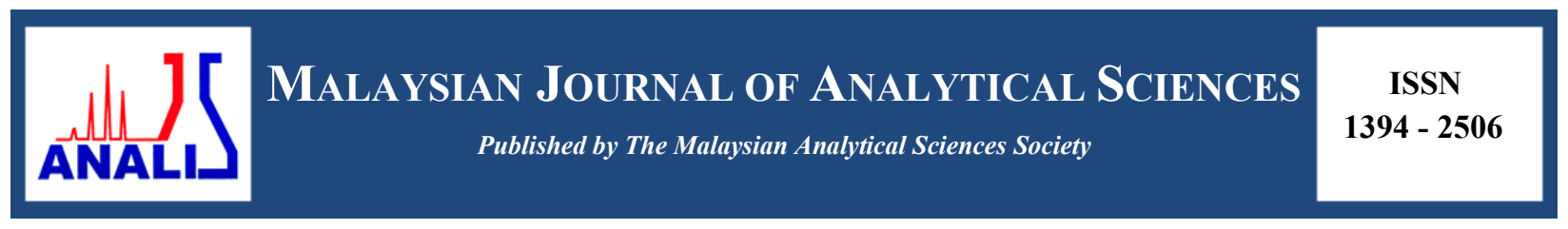

\title{
EFFECT OF NON-IONIC SURFACTANTS TO THE Al(III)-MORIN COMPLEX AND ITS APPLICATION IN DETERMINATION OF Al(III) IONS: A PRELIMINARY STUDY
}

\author{
(Kesan Surfaktan Tak-Ionik Kepada Kompleks Al(III)-Morin dan Aplikasinya dalam Penentuan \\ Ion Al(III): Satu Kajian Awal)
}

\author{
Faiz Bukhari Mohd Suah ${ }^{1}$, Musa Ahmad ${ }^{2}$, Faizatul Shimal Mehamod ${ }^{3}$ \\ ${ }^{1}$ School of Chemical Sciences, \\ Universiti Sains Malaysia, 11800 Minden, Pulau Pinang, Malaysia \\ ${ }^{2}$ Faculty of Science \& Technology, \\ Universiti Sains Islam Malaysia, Bandar Baru Nilai, 71800 Nilai, Negeri Sembilan, Malaysia \\ ${ }^{3}$ School of Fundamental Science, \\ Universiti Malaysia Terengganu, 21030 Kuala Terengganu, Terengganu, Malaysia
}

*Corresponding author: fsuah@usm.my

Received: 5 October 2016; Accepted: 11 May 2017

\begin{abstract}
A simple and sensitive spectrofluorimetric method for the determination of $\mathrm{Al}(\mathrm{III})$ based on the formation of Al-Morin-Triton X100 ternary complex is described. The effect of other non-ionic surfactants, such as Tween 80 , Tween 20 and octylglucoside (OG) on fluorescence analysis were also studied. The addition of Triton X-100 makes feasible the fluorimetric determination of submicrogram quantities of $\mathrm{Al}(\mathrm{III})$. The complex was excited at $410 \mathrm{~nm}$ and the fluorescence signal was measured at $495 \mathrm{~nm}$. Maximum fluorescence signal was produced at $\mathrm{pH} 4.0$ (acetic acid-acetate buffer), with $0.6 \%$ Triton X-100 and $1.35 \times 10^{-3}$ mol $\mathrm{L}^{-1}$ Morin. The calibration graph is linear up to $7 \mathrm{mg} \mathrm{L}^{-1}$ and the detection limit is $0.022 \mathrm{mg} \mathrm{L}^{-1}$. The relative standard deviation is $1.81 \%$ for $\mathrm{Al}(\mathrm{III})$ at $5 \mathrm{mg} \mathrm{L}^{-1}$. It was found that $\mathrm{Zn}(\mathrm{II})$ and $\mathrm{F}^{-}$produced highest interference.
\end{abstract}

Keywords: aluminum determination, fluorescence analysis, non-ionic surfactants, Triton X-100, Morin

\section{Abstrak}

Satu kaedah penentuan Al(III) secara spektrofluorimetri yang mudah dan sensitif berasaskan kepada pembentukan kompleks ternari Al-Morin-Triton X-100 dilaporkan. Kesan beberapa surfaktan tak-ionik yang lain seperti Tween 20, Tween 80 dan ositilglukos (OG) terhadap analisis berpendarflour turut dikaji. Penambahan Triton X-100 telah membolehkan penentuan secara pendarflour Al(III) dijalankan sehingga kepada kuantiti submikrogram. Kompleks teruja pada $410 \mathrm{~nm}$ dan isyarat pendarflour diukur pada $495 \mathrm{~nm}$. Isyarat pendarflour maksimum dihasilkan pada pH 4.0 (menggunakan penimbal asetik asid-asetat), dengan $0.6 \%$ Triton X-100 dan $1.35 \times 10^{-3} \mathrm{~mol} \mathrm{~L}^{-1}$ morin. Graf kalibrasi adalah linear sehingga $7 \mathrm{mg} \mathrm{L}^{-1}$ dan had pengesanan pula adalah $0.022 \mathrm{mg} \mathrm{L}^{-1}$. Sisihan piawai relatif bagi penentuan $5 \mathrm{mg} \mathrm{L}^{-1} \mathrm{Al}(\mathrm{III})$ ialah $1.81 \%$. Didapati juga ion $\mathrm{Zn}$ (II) dan $\mathrm{F}^{-}$menghasilkan gangguan bacaan yang tertinggi.

Kata Kunci: penentuan aluminum, analisis fluorimetrik, surfaktan tak-ionik, Triton X-100, Morin

\section{Introduction}

It is known that $\mathrm{Al}(\mathrm{III})$ is a minor component in natural waters, its concentration being largely controlled by its low solubility, with typical levels in the range $0.5-5 \mu \mathrm{g} \mathrm{L}^{-1}$ in seawater and $10-140 \mu \mathrm{g} \mathrm{L}^{-1}$ in fresh waters [1]. As for 
drinking water, the World Health Organization (WHO) has set the standard permissible level of Al(III) in drinking water at $200 \mu \mathrm{g} \mathrm{L}^{-1}$ [2]. $\mathrm{Al}(\mathrm{III})$ ions also present several neurotoxic effects, and it has been suspected that $\mathrm{Al}(\mathrm{III})$ may be responsible for the cause of Alzheimer's disease, toxic effects on patients with renal failure and bone softening [3]. Sensitive analytical procedures are therefore required to study and monitor its level in the environment and its toxicology. While several methods have been developed for the determination of $\mathrm{Al}(\mathrm{III})$, spectrophotometry [4-6] and spectrofluorimetry [7-10] are the preferred techniques due to their simplicity, high precision and accuracy, high sensitivity, low cost and widespread availability of equipment.

Surfactants have been successfully used to improve current analytical techniques and in developing new ones. In micellar media, the sensitivity, selectivity and stability constants of reactions are greatly enhanced, and metal complex reactions are among them. As for fluorometric analysis, the intensity of molecular fluorescence is greatly influenced by the solvent effect and the presence of quenching impurities in the solvent. In some cases, it is possible to enhance the fluorescence and minimize the interferences by the incorporation of surfactants into the solution to be studied. The reasons for the increased fluorescence intensity in micellar solutions are not fully understood. Several mechanisms have been proposed by various authors. According to Sanz-Medel et al. in 1987, it is most likely due to (i) the effect of solubilization of neutral chelates and ligands within the micellar aggregates and (ii) the interaction of ionic complexes with surfactant molecules and aggregates having opposite charge [11]. Alternatively, Hinze et al. in 1984 proposed that the effect of the micelle appeared to result from the protection of the metal chelate from quenching in the bulk solvent [12]. From the literature, we have found that the use of cationic and anionic surfactants has little impact on enhancing the intensity of the metal-morin complexes; on the contrary, those surfactants decrease the fluorescence intensity and create unstable ternary complexes [13-15]. Therefore, we have decided to focus only on the use of non-ionic surfactants.

This paper investigated the reaction of $\mathrm{Al}(\mathrm{III})$ and morin in the presence of polyoxyethylene(9.5)-t-octyl-phenol (Triton X-100) and its potential for the determination of aqueous $\mathrm{Al}(\mathrm{III})$. The influences of various non-ionic surfactants on the fluorescence intensity of the $\mathrm{Al}(\mathrm{III})$-Morin complex and their characteristics were also studied.

\section{Instrument}

\section{Materials and Methods}

Fluorescence spectra were obtained using Perkin-Elmer LS55 fluorescence spectrometer operated with $5.0 \mathrm{~nm}$ for excitation and emission slits.

\section{Reagents}

All chemicals used were analytical grade unless stated otherwise. All solutions were prepared by using MilliQ distilled deionized water. Reagents used in this study were aluminum potassium sulphate dodecahydrate (Merck), morin (Fluka), polyoxyethylene(9.5)-t-octyl-phenol (Triton X-100), (Fluka), polyoxyethylene (20)sorbitol monolaurate (Tween 20), (BDH), polyoxyethylene(20)sorbitol mono-oleate (Tween 80), (BDH), octylglucoside (OG), (BDH) and ethanol 95\% (Hmbg. Chemical).

The Al(III) stock solution $\left(10 \mathrm{mgL}^{-1}\right)$ was prepared daily by dissolving $0.1758 \mathrm{~g}$ of aluminium potassium sulphate dodecahydrate in water, adding $1 \%(\mathrm{v} / \mathrm{v})$ sulphuric acid and diluting to $1 \mathrm{~L}$ with water. The morin solution $(5.0 \times$ $10^{-3} \mathrm{~mol} \mathrm{~L}^{-1}$ ) was prepared by dissolving $0.1691 \mathrm{~g}$ of morin in $85 \mathrm{~mL}$ of $95 \%$ ethanol and diluting to $100 \mathrm{~mL}$ with water. All surfactants were used without further purification. The surfactants used in this study were prepared by diluting the surfactants to the percent required with water.

All of the buffer solutions (acetic acid-sodium-acetate buffer system), standard solutions for $\mathrm{Al}(\mathrm{III})$, ethanolic morin solution and non-ionic surfactants were prepared at room temperature of $25^{\circ} \mathrm{C}$. The $\mathrm{pH}$ was measured to a $\mathrm{pH}$ of \pm 0.01 with a Hanna Instrument model HI 2211 pH Meter.

\section{General procedure}

To a solution containing $2 \mathrm{~mL}$ of $\mathrm{Al}(\mathrm{III})$, add $2 \mathrm{~mL}$ of buffer, $1 \mathrm{~mL}$ of morin solution $\left(1.35 \times 10^{-5} \mathrm{~mol} \mathrm{~L}^{-1}\right)$ and $3 \mathrm{~mL}$ of aqueous $0.6 \% \mathrm{v} / \mathrm{v}$ Triton X-100 solution. The mixture was diluted to volume in $25 \mathrm{~mL}$ standard flask with MilliQ water. The sample should be shaken briskly immediately prior to measurement the fluorescence. The fluorescence 
intensity was measured at $495 \mathrm{~nm}$, with excitation at $410 \mathrm{~nm}$. All measurements were carried out three times, unless stated otherwise.

\section{Results and Discussion}

An initial study was carried out to identify the level of the fluorescence enhancement obtained from a variety of non-ionic surfactants. It was found that sustained and superior enhancement was observed with the use of Triton X100 compared with the other non-ionic surfactants (Figure 1). It is obvious that certain operational and preparation difficulties could be encountered with some surfactants, e.g. OG. High-viscosity materials were difficult to dissolve and could lead to phase separation if left overnight. Therefore, vigorous shaking of the samples must be performed immediately after the addition of the surfactant and again before the fluorescence measurements to obtain a homogeneous micelle system. Based on the degree of enhancement and the ease of operation, Triton X-100 was selected for further study.

The significance of the order of reagent addition was also examined. It was found that the fluorescent enhancement and its maximum intensity did not depend on this. The order of addition chosen was as follows: an aliquot of $\mathrm{Al}(\mathrm{III})$, the addition of acetic acid-acetate ion buffer solution, followed by morin solution and finally an aqueous Triton X-100 solution.

In common with all fluorescence techniques, the sensitivity is basically determined by the choice of an appropriate tool and working conditions. In this study, the experimental precision and sensitivity were found to be very dependent on reagent mixing. Therefore, the solutions should be briskly mixed immediately prior to measuring the fluorescence intensity.

The emission spectra of the Al(III)-morin complex in the presence of non-ionic surfactants are shown in Figure 1. It was found that the addition of Triton X-100 produced about fivefold enhancement and stabilization of fluorescence. The maximum fluorescence was obtained at $495 \mathrm{~nm}$, corresponding to excitation at $410 \mathrm{~nm}$. The enhancement of the fluorescent emission of Al-morin-Triton X-100 is owing to the surfactant's capabilities to (i) increase the solubility of hydrophobic species; (ii) create the microenvironment capable of producing a favourable polarity and acid-base equilibrium that in turn enhance its fluorescence efficiency and (iii) adopt a structure that protects the fluorescence of the analyte from external quenching. In addition, the unique structure of Triton X-100, which has a much shorter hydrophobic tail than the three other surfactants (Tween 20, Tween 80 and OG), also plays a massive role in enhancing the fluorescent emission of the ternary complex. According to Simoncic and Kert [16], the short hydrophobic tail of Triton X-100 can increase the hydrophobicity of the ternary complex and at the same time increases the attractive force (including van der Waals attraction between hydrocarbon parts) between $\mathrm{Al}(\mathrm{III})$ and morin. Therefore, it was found that Triton X-100 is also capable of enhancing the fluorescent emission compared with other non-ionic surfactants due to its distinctive structure, increasing the complex's hydrophobicity and the attractive force between $\mathrm{Al}(\mathrm{III})$ and morin.

Red-shifts (of around $20 \mathrm{~nm}$ ) were observed in the fluorescence spectra of the Al(III) complexes in the presence of Triton X-100 and Tween 20. The red-shifts of $\lambda_{\mathrm{em}}$ in the presence of non-ionic surfactants show that the contact between the Al(III) complex and non-ionic surfactants causes the excited state of the complex molecule to transform. According to Carrion Dominguez and Cirugeda [17], the Al(III) complexes may be fixed by the nonionic surfactant, thus made more rigid and therefore the fluorescence quantum yield is increased.

The effect of the reaction variables on the fluorescence of the Al(III)-morin-Triton X-100 system was also studied. The fluorescence intensity of the Al(III)-morin-Triton X-100 system was measured over a variety of $\mathrm{pH}$ conditions in the range $2.0-7.0$. The optimum $\mathrm{pH}$ was 4.0 (Figure 2) and the buffer solutions were prepared from acetic acid and sodium acetate. The result, (optimum $\mathrm{pH}$ at 4.0 ) was almost the same as reported in the literature, which used morin as the indicator but Genapol PF-20 as the surfactant [18]. Intensity measurements were recorded at the excitation and emission wavelengths giving the maximum intensity. In addition, these results were blank-corrected to minimize contributions from the variable composition buffer components. 


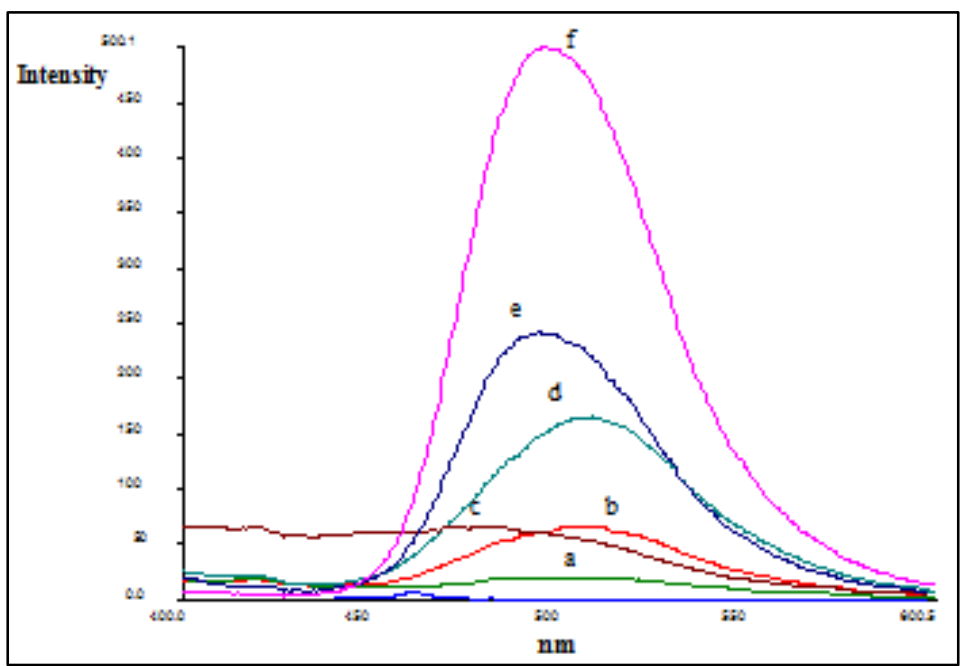

Figure 1. Emission spectra of (a) Al(III), (b) morin, (c) Al-morin-Tween 80, (d) Al-morin, (e) Al-morin-tween 20 and (f) Al-morin-Triton X-100. Conditions: Al(III) $5 \mathrm{mg} \mathrm{L}^{-1}$; morin concentration $1.35 \times 10^{-5} \mathrm{~mol} \mathrm{~L}^{-1}$; Triton X-100 $0.6 \% \mathrm{v} / \mathrm{v} ; \mathrm{pH} 4.0 ; \lambda_{\mathrm{ex}} 410 \mathrm{~nm} ; \lambda_{\mathrm{em}} 495 \mathrm{~nm}$

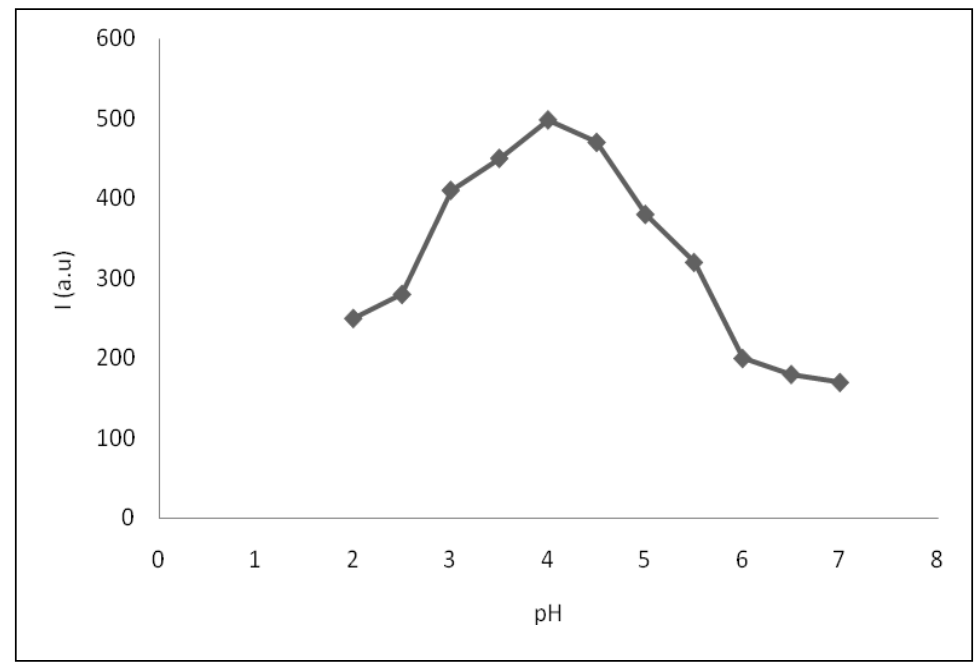

Figure 2. Effect of $\mathrm{pH}$ on the fluorescence intensity obtained from a $5 \mathrm{mg} \mathrm{L}^{-1} \mathrm{Al}(\mathrm{III})$ solution. Conditions: morin concentration $1.35 \times 10^{-5} \mathrm{~mol} \mathrm{~L}^{-1}$; Triton X-100; $0.6 \% \mathrm{v} / \mathrm{v}$

The influence of the concentration of Triton X-100 on fluorescence intensity was studied with fixed concentration of $\mathrm{Al}(\mathrm{III})$ and morin and variable concentrations of Triton $\mathrm{X}-100$ between 0 and $0.8 \% \mathrm{v} / \mathrm{v}$. It was observed that as the Triton X-100 concentration increased, the fluorescence intensity increased until it reached $0.6 \% \mathrm{v} / \mathrm{v}$ (Figure 3). These gradual increases are attributable to the increased viscosity produced at the higher concentrations.

As mentioned by Hinze et al. in 1984, the metal complex and ligand compete in their interaction with the surfactant [12]. The ligand requires a surfactant concentration only slightly higher than the critical micelle concentration to achieve optimum interaction with the surfactant, whereas the complex requires a significantly higher concentration to yield maximum fluorescence. The viscous effect at high surfactant concentrations is not appreciable for morin alone. In all cases, the increase in fluorescence of the complex is much higher than with morin alone. 


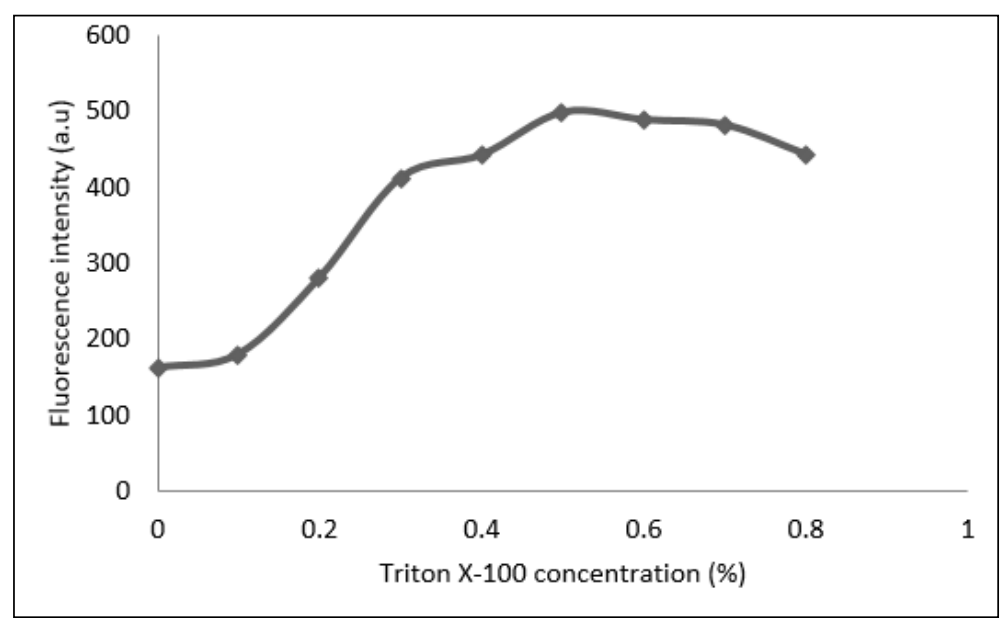

Figure 3. Effect of Triton X-100 concentration on the fluorescence intensity. Conditions: $\mathrm{Al}(\mathrm{III}) 5 \mathrm{mg} \mathrm{L}^{-1}$; morin concentration $1.35 \times 10^{-5} \mathrm{~mol} \mathrm{~L}^{-1}$; Triton X-100 $0.6 \% \mathrm{v} / \mathrm{v} ; \mathrm{pH} 4.0 ; \lambda_{\mathrm{ex}} 410 \mathrm{~nm} ; \lambda_{\mathrm{em}} 495 \mathrm{~nm}$

Figure 4 shows the effect of morin concentration at a fixed concentration of $\mathrm{Al}(\mathrm{III})\left(5 \mathrm{mg} \mathrm{L}{ }^{-1}\right)$ and Triton X-100 $(0.6 \% \mathrm{v} / \mathrm{v})$. The fluorescence intensity of the complex is almost constant in the morin concentration range $1.35 \times$ $10^{-5}-1.70 \times 10^{-5} \mathrm{~mol} \mathrm{~L}^{-1}$. This optimum concentration range was achieved because these morin concentrations were sufficient to yield the Al(III)-morin complex in the presence of Triton X-100. This concentration $\left(1.35 \times 10^{-5}\right.$ $\mathrm{mol} \mathrm{L}^{-1}$ ) was therefore employed for further studies.

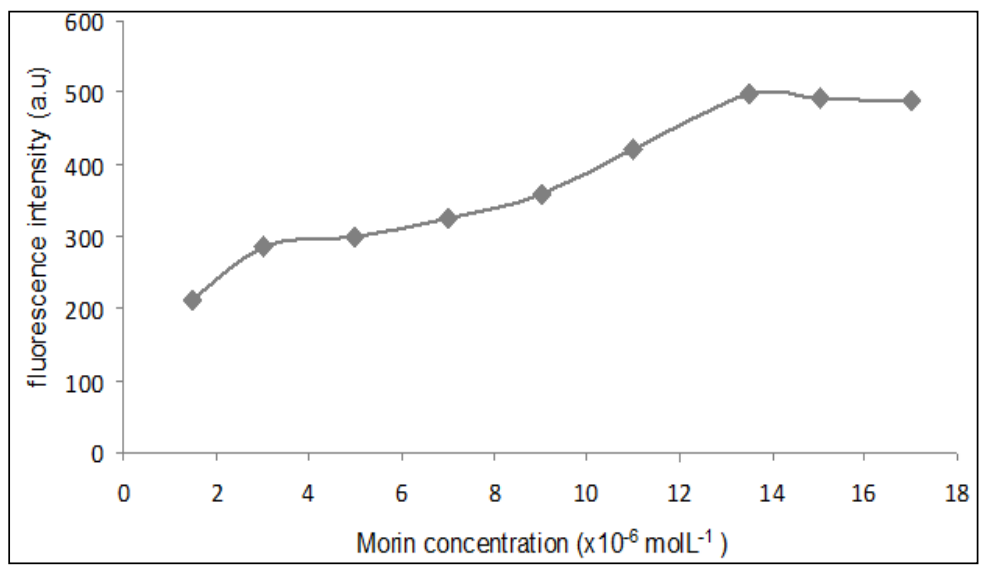

Figure 4. Effect of morin concentration to the formation of Al-morin-Triton X-100 complex. Conditions: Al(III), 5 mg L-1; Triton X-100, $0.6 \% \mathrm{v} / \mathrm{v}$

In addition, it is expected that a decrease in fluorescence intensity at higher morin concentrations will occur [19]. This is due to the higher self-quenching effect (the tendency of ions to collide with each other) that occurs between $\mathrm{Al}(\mathrm{III})$ and morin at higher concentrations of morin.

The calibration curve of $\mathrm{Al}(\mathrm{III})$ concentration versus relative fluorescence intensity $\left(\left(I-I_{0}\right) / I_{0}\right)$ is shown in Figure 5 , where $I$ was the measured fluorescence intensity at any $\mathrm{Al}(\mathrm{III})$ concentration and $I_{0}$ was the intensity in the absence of $\mathrm{Al}(\mathrm{III})$. 


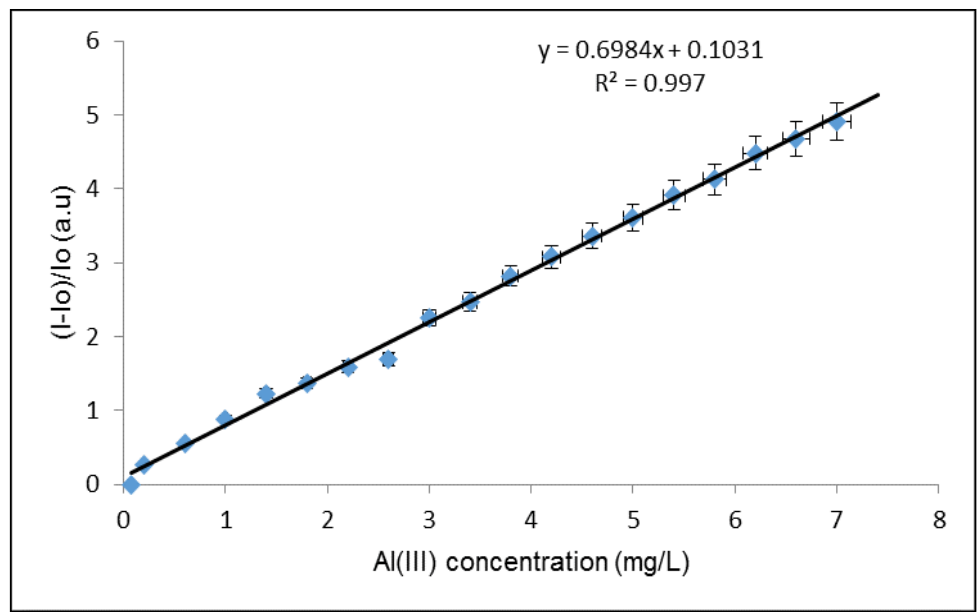

Figure 5. Calibration curve for $\mathrm{Al}(\mathrm{III})$-morin-Triton $\mathrm{X}-100$ complex system. Conditions: $\mathrm{Al}(\mathrm{III}) 5 \mathrm{mgL}^{-1}$; morin concentration $1.35 \times 10^{-5} \mathrm{~mol} \mathrm{~L}^{-1}$; Triton X-100 $0.6 \% \mathrm{v} / \mathrm{v} ; \mathrm{pH} 4.0 ; \lambda_{\mathrm{ex}} 410 \mathrm{~nm} ; \lambda_{\mathrm{em}} 495 \mathrm{~nm}$

The morin-Triton X-100 complex exhibited a linear emission response to $\mathrm{Al}(\mathrm{III})$ in the concentration range of $1.30 \times 10^{-6}-2.59 \times 10^{-4} \mathrm{~mol} \mathrm{~L}^{-1}\left(0.035-7.0 \mathrm{mg} \mathrm{L}^{-1}\right)$ with a correlation coefficient of $r=0.997$. The detection limit (the concentration of the metal ion giving a signal equal to the blank signal plus three standard deviations of the blank) was found to be $0.022 \mathrm{mg} \mathrm{L}^{-1}$. The calculated relative standard deviation, R.S.D., for eight replicate analyses of a sample containing $5 \mathrm{mg} \mathrm{L}^{-1}$ of $\mathrm{Al}(\mathrm{III})$ was $1.81 \%$.

The effect of various species present in the samples was studied too. A sample containing $2 \mathrm{mgL}^{-1} \mathrm{Al}(\mathrm{III})$ was prepared in the presence of $10 \mathrm{mgL}^{-1}$ of $\mathrm{Mg}(\mathrm{II}), \mathrm{Cu}(\mathrm{II}), \mathrm{Zn}(\mathrm{II}), \mathrm{Fe}(\mathrm{III}), \mathrm{Ca}(\mathrm{II}), \mathrm{Ba}(\mathrm{II}), \mathrm{Cl}^{-}, \mathrm{F}^{-}$and $\mathrm{SO}_{4}{ }^{2-}$. The results shown in Table 1 indicate little or no interference is observed in the presence of $\mathrm{Mg}(\mathrm{II}), \mathrm{Ca}(\mathrm{II}), \mathrm{Ba}$ (II), $\mathrm{Cl}^{-}$and $\mathrm{SO}_{4}{ }^{2-}$. However, $\mathrm{Cu}$ (II) $\mathrm{Zn}(\mathrm{II})$ and $\mathrm{Fe}(\mathrm{III})$ gave lower recovery due to slight quenching effect of these species on the fluorescence intensity of the $\mathrm{Al}(\mathrm{III})-$ morin-Triton X-100 complex. Interference from $\mathrm{Fe}(\mathrm{III})$ is expected since the ionic radius of $\mathrm{Fe}$ (III) is similar to the $\mathrm{Al}(\mathrm{III})$ ion. $\mathrm{As}$ for $\mathrm{Cu}(\mathrm{II})$ and $\mathrm{Zn}$ (II) ions, the interferences are due to the tendency of morin to form $\mathrm{Cu}(\mathrm{II})$-morin and $\mathrm{Zn}$ (II)-morin complexes. However, the recovery could be improved with an introduction of 1,10-phenanthroline for reducing or eliminating the interferences of $\mathrm{Fe}$ (III) and hydroxylamine for $\mathrm{Cu}$ (II) to the samples as the masking agents [20]. As for the significant interference from $\mathrm{F}^{-}$, it is also predicted since $\mathrm{Al}(\mathrm{III})$ forms a stable complex with this anion. Therefore, it is recommended that large amount of $\mathrm{Be}(\mathrm{II})$ as berilium chloride should be tried as to improve the recovery of $\mathrm{Al}(\mathrm{III})$ [21].

Table 1. Effect of interfering species on the recovery of $2 \mathrm{mg} \mathrm{L}^{-1} \mathrm{Al}(\mathrm{III})$ ion. Conditions: morin $1.35 \times 10^{-5} \mathrm{~mol} \mathrm{~L}^{-1}$; Triton X-100 $0.6 \% \mathrm{v} / \mathrm{v}$.

\begin{tabular}{lc}
\hline Species Added $\left(\mathbf{1 0 ~} \mathbf{~ m L}^{-\mathbf{1}}\right)$ & Recovery \pm R.S.D\% \\
\hline $\mathrm{Mg}^{2+}$ & $106.5 \pm 1.8$ \\
$\mathrm{Cu}^{2+}$ & $70.2 \pm 1.1$ \\
$\mathrm{Zn}^{2+}$ & $62.8 \pm 1.2$ \\
$\mathrm{Fe}^{3+}$ & $68.8 \pm 1.2$ \\
$\mathrm{Ca}^{2+}$ & $97.9 \pm 1.2$ \\
$\mathrm{Ba}^{2+}$ & $102.8 \pm 1.6$ \\
$\mathrm{Cl}^{-}$ & $105.2 \pm 1.2$ \\
$\mathrm{~F}^{-}$ & $45.6 \pm 1.8$ \\
$\mathrm{SO}_{4}{ }^{2-}$ & $104.4 \pm 1.1$ \\
\hline
\end{tabular}




\section{Conclusion}

The procedure described in this research offers a substantial improvement compared to other method, which utilizing an extraction steps in determination of $\mathrm{Al}(\mathrm{III})$ by fluorescence method. The use of Triton $\mathrm{X}-100$ has eliminates the need to use an additional extraction steps for the sensitive and selective determination of $\mathrm{Al}$ (III). A five-fold sensitivity increased in the fluorimetric determination of $\mathrm{Al}(\mathrm{III})$ using morin was obtained by the addition of Triton X-100. The optimum conditions obtained at $\mathrm{pH} 4.0$ in the presence of $1.35 \times 10^{-5} \mathrm{~mol} \mathrm{~L}^{-1}$ morin and $0.6 \%$ $\mathrm{v} / \mathrm{v}$ Triton X-100. A wide calibration range of $1.30 \times 10^{-6}-2.59 \times 10^{-4} \mathrm{~mol} \mathrm{~L}^{-1}\left(0.035-7.0 \mathrm{mg} \mathrm{L} \mathrm{m}^{-1}\right)$ and the detection limit of $0.022 \mathrm{mg} \mathrm{L}^{-1}$ were achieved too by using the proposed method. Further study will be taken to apply this method to determine $\mathrm{Al}(\mathrm{III})$ ion in the real samples.

\section{Acknowledgements}

The authors would like to acknowledge financial support from Ministry of Higher Education of Malaysia (Grant FRGS 1/2011/ST/USIM/01/1) and Universiti Sains Islam Malaysia (Grant PPP/FST-05-12711) for this work.

\section{References}

1. Tria, J. C. V. Butler, E. C. V. Haddad, P. R. and Bowie, A. R. (2007). Determination of aluminium in natural water samples. Analytica Chimica Acta, 588: $153-165$.

2. Dilleen, J. W. Birch, B. J. and Hagget, B. G. D. (1999). Electrochemical detection of aluminium using singleuse sensors. Analytical Communications, 36: 363 - 365.

3. Flaten, T. P. (2001). Aluminium as a risk factor in Alzheimer's disease, with emphasis on drinking water. Brain Research Bulletin, 55(2): 187 - 196.

4. Ghavami, R., Najafi, A. and Hemmateenejad, B. (2008). Chemometrics-assisted spectrophotometric methods for simultaneous determination and complexation study of $\mathrm{Fe}(\mathrm{III}), \mathrm{Al}(\mathrm{III})$ and $\mathrm{V}(\mathrm{V})$ with morin in micellar media. Spectrochima Acta Part A, 70: 824 - 834.

5. Carpani, I. Scavetta, E. and Tonelli, D. (2004). Spectrophotometric determination of aluminium and nickel. Annali di Chimica, 94: 365 - 372.

6. Guray, T. Uysal, U. D. Gedikbey, T. and Huseyinli, A. A. (2005). 2, 2', 3,4-tetrahydroxy-3'-sulpho-5'nitroazobenzene for spectrophotometric determination of aluminium in pharmaceutical suspensions and granite. Analytical Chimica Acta, 545: 107 - 112.

7. Hernandez, F. H. and Esriche, J. M. (1984). Fluorimetric determination of aluminium with morin after extraction with isobutyl methyl ketone. Part I. Fluorescence of the aluminium-morin complex in an isobutyl methyl ketone- ethanol- water system. Analyst, 109: 1585 - 1588.

8. Brach-Papa, C. Coulomb, B. Théraulaz, F. Van Loot, P. Boudenne, J. L. Branger, C. and Margaillan, C. (2004). Fluorimetric determination of aluminium in water by sequential injection through column extraction. Analytical and Bioanalytical Chemistry, 378: $1652-1658$.

9. Al-Kindy, S. M. Z. Suliman, F. O. and Salama, S. B. (2003). A sequential injection method for the determination of aluminium in drinking water using fluorescence enhancement of the aluminum-morin complex in micellar media. Microchemical Journal, 74: 173 - 179.

10. Alonso-Mateos, A. Almendral-Parra, M. J. Curto-Serrano, Y and Rodríguez-Martín, F. J. (2008). Online monitoring of aluminium in drinking water with fluorimetric detection. Journal of Fluorescence, 18: 183 - 192.

11. Sanz-Medel, A. De La Campa, R. F. and Garcia Alonso, J. I. (1987). Metal chelate fluorescence enhancement in micellar media: mechanisms of surfactant action. Analyst, 112: $493-497$.

12. Hinze, W. L. Singh, H. N. Baba, Y. and Harvey, N. G. (1984). Micellar enhanced analytical fluorimetry. Trends in Analytical Chemistry, 3: 193 - 199.

13. Howard, A. G. Coxhead, A. J. Potter, I. A. and Watt, A. P. (1986). Determination of dissolved aluminium by the micelle-enhanced fluorescence of its lumogallion complex. Analyst, 111: 1379-1382.

14. Diaz Garcia, M. E. and Sanz-Medel, A. (1986). Dye-surfactant interactions: A review. Talanta, 33: 255 - 264.

15. Nakahara, Y. Kida, T. Nakatsuji, Y. and Akashi, M. (2004). A novel fluorescent indicator for $\mathrm{Ba}^{2+}$ in aqueous micellar solutions. Chemical Communications, 2: $224-225$.

16. Simoncic, B. and Kert, M. (2008). Influence of the chemical structure of dyes and surfactants on their interactions in binary and ternary mixture. Dyes and Pigments, 76: $104-112$. 
Faiz Bukhari et al: EFFECT OF NON-IONIC SURFACTANTS TO THE Al(III)-MORIN COMPLEX AND ITS APPLICATION IN DETERMINATION OF Al(III) IONS: A PRELIMINARY STUDY

17. Carrion Dominguez, J. L. and Cirugeda, M. D. L. G. (1987). Spectroscopic study of the aluminium/lumogallion system in the presence of non-ionic surfactants. Analytical Chimica Acta, 198: 53 - 61 .

18. Escriche, J. M., Cirugeda, M. D. L. G. and Hernandez, F. H. (1983). Increase in the sensitivity of the fluorescent reaction of the complexing of aluminium with morin using surfactant agents. Analyst, 108: $1386-$ 1391.

19. Hernandez, F. H. Esriche, J. M. and Andreu, M. T. G. (1986). Enhancement of the fluorescence of the zincmorin complex by non-ionic surfactant. Talanta, 33: $537-540$.

20. Ren, J. L. Zhang, J. Luo, J. Q. Pei, X. K. and Jiang, Z. X. (2001). Improved fluorimetric determination of dissolved aluminium by micelle-enhanced lumogallion complex in natural waters. Analyst, 126: 698 - 702 .

21. Zhang, J. Xu, H. and Ren, J. L. (2000). Fluorimetric determination of dissolved aluminium in natural waters after liquid-liquid extraction into n-hexanol. Analytical Chimica Acta, 405: 31 - 42. 